\title{
小児の無酸素性パワーに対する低温暴露の影響
}

\author{
岩 田 学*1 近藤 和泉*2 細川賀乃子*2 相 馬 正始*3 \\ Rebecca Martin HenRY*4 Oded BAR-OR*4
}

\section{Effects of Cold Exposure on Anaerobic Power of Children}

\author{
Manabu Iwata, ${ }^{* 1}$ Izumi Kondo, ${ }^{* 2}$ Kanoko HosoKawa, ${ }^{* 2}$ Masashi Soma, ${ }^{* 3}$ \\ Rebecca Martin Henry, ${ }^{* 4}$ Oded BAR-OR ${ }^{* 4}$
}

\begin{abstract}
The effects of cold exposure on the anaerobic power of children were studied using the Wingate anaerobic test (WAnT). Twelve healthy boys aged 9-13 years participated in the study. A climatic chamber was used for cold exposure. Two respective WAnTs were conducted at an interval of 2 minutes after 30 minutes of rest in thermoneutral conditions $\left(23^{\circ} \mathrm{C}, 40 \%\right.$ relative humidity) and cold conditions $\left(5^{\circ} \mathrm{C}, 40 \%\right.$ relative humidity). Comparison of the mean power in the first WAnT between the two conditions did not show statistical significance. The percent recovery was calculated by dividing the second WAnT value by the first WAnT value for each condition. The percent recovery in the cold conditions was lower than that in the thermoneutral conditions, and it was statistically significant $(p<0.05)$. These results indicated that cold exposure did not affect the anaerobic power of children but delayed its recovery. (Jpn J Rehabil Med 2001; 38 : 981-985)
\end{abstract}

要 旨: 低温暴露が小児の無酸素性パワーに与える影響について, ウインゲート無酸素性テ スト（WAnT）を用いて検討した。被験者は 9 13 歳の健常男子 12 名であった. 低温暴露に は人工気象室を使用し，常温環境 $\left(23^{\circ} \mathrm{C}\right.$, 相対湿度 $40 \%$ ） と低温環境 $\left(5^{\circ} \mathrm{C}\right.$, 相対湿度 $\left.40 \%\right)$ で 30 分間の安静の後, それぞれ WAnT を 2 分間の休螅をはさんで 2 回施行した。両温度環 境の 1 回目の WAnT における mean power の比較では, 有意差が認められなかった. 各々の 温度環境において 2 回目の WAnT の mean power 1 回目の WAnT の mean power で除し て算出した回復率の比較では，低温環境において回復率が有意に低下していた．以上より低温 暴露は小児の無酸素性パワーに影響を与えないが，回復を遅延させると考えられた。（リハ医 学 $2001 ; 38: 981-985)$

Key words : ウインゲート無酸素性テスト (Wingate anaerobic test), 冷却 (cooling), 人工気象室 (climatic chamber), 皮膚温 (skin temperature), 直腸温 (rectal temperature)

2001 年 8 月 15 日受付, 2001 年 11 月 1 日受理

*1 弘前大学医学部保健学科理学療法学専攻/T 036-8564 青森県弘前市本町 66-1

Department of Physical Therapy, School of Health Sciences, Hirosaki University

*2 弘前大学医学部脳神経血管病態研究施設機能回復部門/ $7036-8562$ 青森県弘前市在府町 5

Department of Rehabilitation Medicine, Institute of Brain Science, Hirosaki University School of Medicine

*3 弘前大学医学部附属病院理学療法部/ ₹ 036-8563 青森県弘前市本町 53

Rehabilitation Center, Hirosaki University Hospital

${ }^{* 4}$ Children's Exercise and Nutrition Centre, McMaster University Chedoke Hospital Division, Evel Bldg., 4th Floor, Hamilton, Ontario L8N $3 Z 5$ Canada 


\section{はじめに}

ウインゲート無酸素性テスト（Wingate anaerobic test：以下 WAnT）は，1970 年代にイスラエルのウ インゲート研究所で開発された 30 秒間の最大努力下 でのサイクリングテストである.このテストでは重鉦 の懸垂によって一定のブレーキングフォースを負荷す ることができる機械式エルゴメータを使用する，被験 者の性別, 年齢, 活動レベル別に, 最も高いパワーを 引き出すための係数が報告されており ${ }^{1)}$, 被験者の体 重とその係数の積によって，被験者ごとに至適重鍾量 が決定される.WAnTはこの懸垂された重錘により 生じるブレーキングフォースとペダルの回転速度の積 として算出されるパワーの 30 秒間の変化をとらえた ものである，このテストから得られる指標は, 最初の 数秒間に最大でどの程度のパワーを発揮できるかを 示す peak power, 30 秒間の平均のパワーを示す mean power, 30 秒間にどの程度疲労したかを示す \%fatigue の 3 つである1).このうち peak power はり ン酸源の無酸素性の代謝過程を反映し, mean power は筋での無酸素性の解糖の比率を反映するとみなさ れており，再現性は mean powerのほうが優れてい る.\%fatigue は peak power との関連性が高いこと に加えて, 被験者ごとのばらつきが大きいため, 多く の研究では体力指標としては使われていない10).

現在この WAnT を用いて, 種々の条件下での無酸 素性パワーの再現性が検討されており, 環境温度の影 響もその 1 つである。低温暴露が成人の無酸素性パワ 一に与える影響について, Crowley らは $12^{\circ} \mathrm{C}, 30$ 分 の水浴で peak power が $30 \%$, mean power が $26 \%$ 低下したと報告している4).また Hackney らは, 96 から 120 時間に及ぶー $2^{\circ} \mathrm{C}$ から $-22^{\circ} \mathrm{C}$ 低温下での軍 事演習が，常温での軍事演習に比較し， peak power で $6.8 \%$, mean power で $6.7 \%$ 低下率が大きかった と述べている8). 一方小児では, 無酸素性運動後の筋 パワーの回復が成人に比較して早いことが知られてい るが9, 無酸素性パワーに対する低温暴露の影響を検 討した研究報告は現在までなされていない。そこで今 回我々は，人工気象室を用いた低温暴露が小児の下肢 の無酸素性パワーとその回復に及ぽす影響について検 討した。

\section{対象および方法}

今回の研究は, McMaster 大学小児運動栄養セン ター（カナダ・オンタリオ州）で行われたものであ り，実験デー夕は筆頭著者と RM Henryが共同で収 集した．被験者は健常白人男児 12 名（平均年齢 11.4 \pm 1.0 歳, 平均身長 $150.9 \pm 8.1 \mathrm{~cm}$, 平均体重 $44.3 \pm$ $6.4 \mathrm{~kg}$, 平均体脂肪率 $21.1 \pm 5.4 \%$, 平均除脂肪体重 $34.8 \pm 4.3 \mathrm{~kg}$, 平均大腿部皮脂厚 $17.8 \pm 7.5 \mathrm{~mm}$, 平 均下腿部皮脂厚 $20.8 \pm 6.7 \mathrm{~mm}$ ）であった。低温暴露 には温度と相対湿度を自由に設定できる人工気象室を 使用し, 常温環境を $23^{\circ} \mathrm{C}$, 相対湿度 $40 \%$, 低温環境 を $5^{\circ} \mathrm{C}$, 相対湿度 $40 \%$ に設定した。 日内変動を避ける ため, デー夕収集は午後 $4 \sim 7$ 時の間に行った。また データ収集の行われた 10〜 12 月のカナダ・オンタリ オ州に抢ける外気温の平均は $5.3^{\circ} \mathrm{C}\left(1.3 \sim 11.2^{\circ} \mathrm{C}\right)$ であった。被験者は 3 回研究室を訪れ，1回目の訪 問では同意書の作成と身体基礎データの収集抢よ びWAnTの練習を行った。WAnTにはFleisch Metabo 社製のサイクルエルゴメータを使用した。 今 回の研究では至適重鍾量決定のための係数として 0.042 （重鍾量を体重の $4.2 \%$ とする）を採用した. 2 回目と 3 回目の訪問で, 常温環境と低温環境における WAnT のデータ収集を行った。施行順の影響を避け るため, 6 名の被験者では最初に常温環境でデー夕収 集を行い, 残りの 6 名の被験者では最初に低温環境で データ収集を行った。被験者の服装は検者側で用意し たスウエットシャツとショートパンツに統一し，両大 腿の $2 / 3$ が露出するように各々の被験者でショートパ ンツの長さを調節した。直腸温測定のため, 深部体温 計（Yellow Springs Instrument 社製, YSI 401) の プローブを肛門括約筋部より直腸内に $10 \mathrm{~cm}$ 挿入し, その位置で固定した。また皮膚温測定のため, 大腿前 面中央部と下腿後面中央部に皮膚温計（Yellow Springs Instrument 社製, YSI 409 B）を貼付した. 被験者は 30 分間, 人工気象室内で安静座位を保ち, その間 5 分おきに直腸温, 大腿および下腿の皮膚温を 測定した. 30 分間の安静座位の後, 1 回目の WAnT を行い, 2 分間休憩した後, 2 回目の WAnT を行っ た。この研究ではデー夕分析の対象を mean power のみとし, mean power の回復率は, 各々の温度環境 において, 2 回目のWAnT の mean power 1 回目 のWAnT の mean power で除して求めた。 統計学的 
分析にはStatView 5.0 J (SAS Institute Inc.) を使 用した。関連 2 群の差の検定に Paired t-test を用い, 危険率 $5 \%$ 未満をもつて有意とした。なおこの研究は McMaster 大学倫理委員会の承認を得て行った.

\section{結果}

\section{1. 直腸温および皮膚温の変化}

常温環境では直腸温および皮膚温の変化は認められ なかった。低温環境では, 直腸温は平均で $0.2 \pm$ $0.37^{\circ} \mathrm{C}$ とわずかに上昇し, 皮膚温は大腿部で平均 8.8 $\pm 1.6^{\circ} \mathrm{C}$, 下腿部で平均 $11.7 \pm 2.2^{\circ} \mathrm{C}$ 低下が認めら れた（図1).

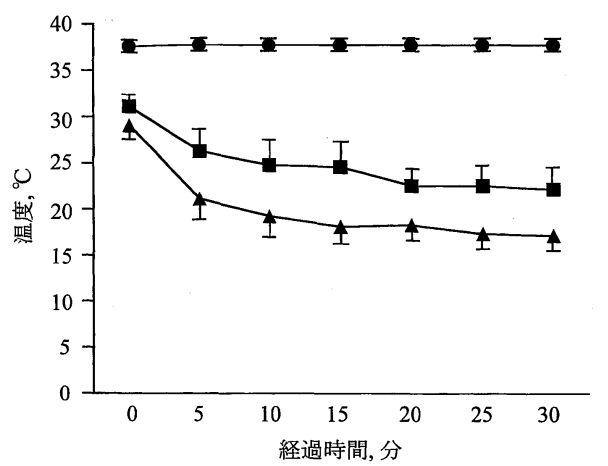

図 1 低温環境における直腸温，皮膚温の変化 $N=12$, - : 直腸温, $\boldsymbol{\square}$ : 大腿部皮膚温, $\boldsymbol{\Delta}$ : 下腿部皮膚 温, 数值は平均值土標準偏差で表示. $5^{\circ} \mathrm{C}, 30$ 分間の低温 暴露で, 直腸温はわずかに上昇し, 皮膚温は著明に低下し た.

\section{2. 常温および低温環境における mean power と mean power $の$ 回復率の比較}

常温環境における体重補正後の mean power の平 均值は $5.8 \pm 0.7 \mathrm{~W} \cdot \mathrm{kg}^{-1}$ であった。一方低温環境に おける体重補正後の mean powerの平均值は $5.8 \pm$ $0.6 \mathrm{~W} \cdot \mathrm{kg}^{-1}$ で, 両者の間に有意差は認められなかっ た (図 $2 \mathrm{a}$ )。常温環境における mean powerの回復 率の平均值は $98.8 \pm 9.3 \%$ で，低温環境における mean power の回復率の平均值は $94.1 \pm 6.2 \%$ で, 統 計学的に有意差 $(p<0.05)$ が認められた（図 $2 \mathrm{~b})$.

\section{考察}

無酸素性パワーをフィールドにおいて測定する場合 には，環境温度の影響について考慮する必要がある。 Dotan らは高温・多湿の条件下では, 小児の無酸素 性パワーが変化しなかったことを報告している5゙.こ の研究は低温環境が小児の無酸素性パワーに及ぼす影 響を検討した初めての報告である。この研究から得ら れた主な知見は， $5^{\circ} \mathrm{C}, 30$ 分間の低温暴露は男児の下 肢の無酸素性パワーを低下させないが，その回復を遅 延させるということである.

この研究では, パワーデータの分析を mean power でのみ行ったが，それは mean power のほうが peak powerより再現性がよく，実験介入による小さな変 化をとらえやすいということ，また今回の研究の被験 者は小児であり，小児は成人に比較して情緒要因によ るモチベーションの変化がデータに影響を及ほしやす く，特に peak powerでそれが顕著である10)という
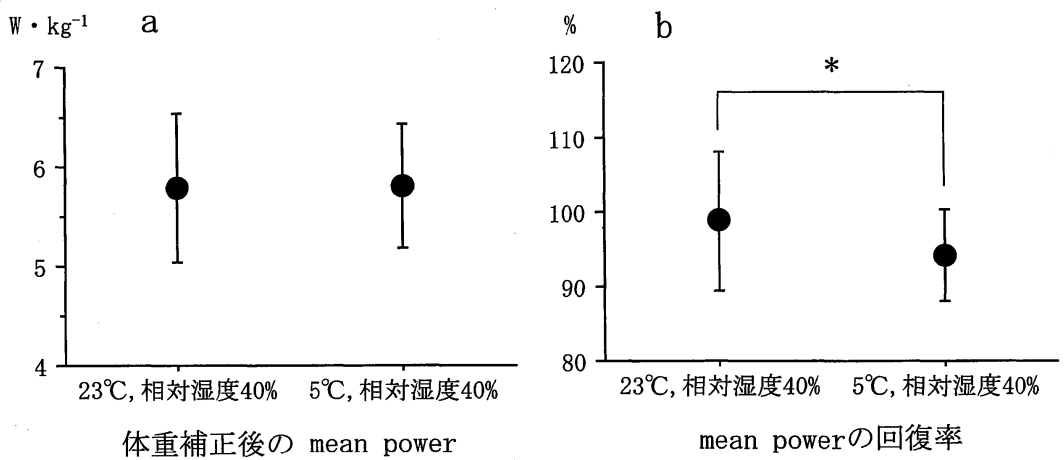

図 2 常温および低温環境における mean power と mean power の回復率の比較 $N=12$, シンボルとエラーバーは平均値士標準偏差を示す. a：体重補正後の mean power の比較，常温環境 $\left(23^{\circ} \mathrm{C}\right.$, 相対湿度 $\left.40 \%\right)$ と低温環境 $\left(5^{\circ} \mathrm{C}\right.$, 相対湿度 $\left.40 \%\right)$ で 有意差を認めなかった。 b：mean power の回復率の比較, 低温環境で回復率が有意に 低下していた。 ${ }^{*} p<0.05$. 
ことがその理由である.

無酸素性の運動能力に影響を与える要因として, 深 部体温の変化が指摘されている. Bergh は深部体温 が $1^{\circ} \mathrm{C}$ 低下するごとに無酸素性の運動能力が $5 \%$ 低下 することを見いだした ${ }^{22}$.また無酸素性パワーの日内 変動に関する研究では, 直腸温は朝方が夕方より約 $0.45^{\circ} \mathrm{C}$ 有意に低く, 無酸素性パワーは朝方が夕方より 約 3.5\%有意に低下していたと報告されている3). 小 児は成人に比較して, 体重あたりの表面積が大きく, 環境温度変化の影響を受けやすい.今回の研究では皮 膚温の低下が著しかったが, 逆に直腸温は $0.2^{\circ} \mathrm{C}$ 上昇 していた. Falk らは同様の条件で成人に低温暴露を 行っているが, その際直腸温は $0.2^{\circ} \mathrm{C}$ 低下したと報告 している6).すなわち低温暴露において，小児では成 人よりも四肢末梢の血管収縮が効果的に行われ，その ため皮膚温は著しく低下する。しかしそれによって冷 却された血液の還流が減少し, 深部体温の低下が緩和 されると考えられる.加えて反応性に全身の代謝が立 進し，冷却による体温低下を補償する十分な熱産生が 行われたため, 結果として深部体温が軽度上昇したも のと思われる。

筋温低下は種々の段階で筋出力に影響を及ぼすとさ れるが，特に物質輸送や代謝は温度の影響を受けやす く, 低温により基質供給や老廃物の除去が阻害される と考えられている4).この点について Ferretti らは, 低温暴露後の筋出力の低下が筋内での ATP の加水分 解や再合成の低下に関連していることを指摘してい $3^{7}$. 今回の低温暴露の条件は, 過去に成人で人工気 象室を使って行われた低温暴露研究6,12) と予備研究の 結果を基に設定した。すなわち極端に低い温度設定で は強い身震いが生じ，その場合は筋温が上昇すると考 えられる。この研究でも, 被験者の多くで軽度の身震 いが観察された。 今回の被験者では, 大腿部で平均 $8.8^{\circ} \mathrm{C}$, 下腿部で平均 $11.7^{\circ} \mathrm{C}$ の皮膚温低下が認められ た. Falk らは $5^{\circ} \mathrm{C}, 30$ 分間という同様の低温条件で, 成人での大腿部の皮膚温の低下が $7^{\circ} \mathrm{C}$ 程度であったこ とを報告しており占，小児では成人より皮膚温低下が 著しいと考えられる．しかし筋温低下については，小 児の場合, 倫理的な理由から穿刺による直接的な筋温 測定が行えず，過去にも報告はない。人工気象室を使 った成人の低温暴露研究において, Oksa らは筋穿刺 によって測定された筋温低下は，同時に測定された皮 膚温低下の 40～50\%程度であったことを報告してい
る ${ }^{12)}$. 先に述べた Crowley らの研究では, 筋温は測 定されていないが, 直腸温が $0.5^{\circ} \mathrm{C}$, 皮膚温は 16 $18^{\circ} \mathrm{C}$ 程度低下したと報告されており ${ }^{4)}, \mathrm{Oksa} ら の$ 研 究結果を参照すると, 筇温の低下は $8^{\circ} \mathrm{C}$ 前後であった と推定される．筋温が $1^{\circ} \mathrm{C}$ 低下するごとに筋のパワー は3\%低下すると言われて抢り ${ }^{13)}$ ，それからすると $26 \%$ mean power 低下は妥当な数値と言える. 今 回の研究では, 大腿部の皮膚温は $8.8^{\circ} \mathrm{C}$ 低下してい た。もし皮膚温と筋温の低下の関係が成人と同様であ ると仮定すれば，筋温は $4^{\circ} \mathrm{C}$ 程度低下することにな り，筋のパワーは計算上 $10 \%$ 程度低下しなければな らない.しかしこの研究で見られた著明な皮膚温低下 は, 深部体温を維持するための生理的反応であったと 考えられ，皮膚温低下と筋温低下の関係は成人と同様 には考えにくい. 加えて小児と成人では身体組成が異 なり，小児は成人より皮脂厚が厚く，特に下肢の皮脂 厚は男子では 11 歳頃が最も厚いとされている ${ }^{11)}$.こ の研究の被験者も大腿部皮脂厚の平均が $17.8 \mathrm{~mm}$,

下腿部皮脂厚の平均が $20.8 \mathrm{~mm}$ であり，この厚い皮 脂厚が低温暴露の筋への影響を減弱させたのではない かと考えられる，加えて低温暴露中に被験者の多くに 身震いが観察されており,この現象は筋温を上昇させ る要因として働いたと考えられる.以上のことから, 今回の研究において低温暴露により筋温低下は生じた と思われるが，その程度がわずかであったため, 深部 体温上昇の影響もあって, 結果として mean power が低下しなかったのではないかと考えられる.

その一方で, 深部体温を保つための生理的反応であ る四肢末梢の血管収縮は，皮膚のみならず筋の血流に も少なからず影響し，それが筋からの疲労代謝物質の 排出を遅らせ, 低温暴露下での無酸素性パワーの回復 を遅延させる結果をもたらしたものと考えられる.

結論として,フィールドにおいて小児の無酸素性パ ワーを測定する場合, 外気温が $5^{\circ} \mathrm{C}$ 程度であれば, 信 頼性のあるデー夕を収集することが可能である。しか し低温環境下では筋パワーの回復に遅延が生じること から, 繰り返しの測定を行う際には四肢の十分な保温 が必要である。

本研究は 1999 年度文部省在外研究においてなされたも のである. 稿を終えるに当たり, 留学の機会を与えてくだ さった弘前大学名誉教授福田道隆先生と弘前大学医学部教 授三浦孝雄先生に深謝いたします。

本論文の要旨は第 37 回日本りハビリテーション医学会 学術集会において発表した。 


\section{文献}

1) Bar-Or O: The Wingate anaerobic test an update on methodology, reliability and validity. Sports Med 1987 ; 4 : 381-394

2) Bergh U: Human power at subnormal body temperature. Acta Physiol Scand (Suppl) 1980 ; 478

3) Bernard T, Giacomoni M, Gavarry O, Seymat M, Falgairette G: Time-of-day effects in maximal anaerobic leg exercise. Eur J Appl Physiol 1998; 77: $133-138$

4) Crowley GC, Garg A, Lohn MS, Van Someren N, Wade AJ : Effect of cooling the legs on performance in a standard Wingate anaerobic power test. Br J Sports Med 1991; 25 : 200-203

5) Dotan R, Bar-Or O : Climatic heat stress and performance in the Wingate anaerobic test. Eur J Appl Physiol 1980 ; 44 : 237-243

6) Falk B, Bar-Or O, Smolander J, Frost G : Response to rest and exercise in the cold: effects of age and aerobic fitness. J Appl Physiol 1994; 76 : 72-78

7) Ferretti G, Ishii M, Moia C, Cerretelli P : Effects of temperature on the muximal instantaneous muscle power of humans. Eur J Appl Physiol 1992; 64: 112-116

8) Hackney AC, Shaw JM, Hodgdon JA, Coyne JT, Kelleher DL: Cold exposure during military operations: effects on anaerobic performance. J Appl Physiol 1991; 71 : 125-130

9) Hebestreit $\mathrm{H}$, Mimura $\mathrm{K}$, Bar-Or O : Recovery of muscle power after high-intensity short-term exercise : comparing boys and men. J Appl Physiol 1993; 74: 2875-2880

10) Inbar $O$, Bar-Or $O$, Skinner JS: The Wingate Anaerobic Test. Human Kinetics, Champaign, 1996

11) Martin AD, Ward R: Body composition. in Measurement in Pediatric Exercise Science (ed by Docherty D). Human Kinetics, Champaign, 1996; pp $87-128$

12) Oksa J, Rintamaki H, Rissanen $S$ : Muscle performance and electromyogram activity of the lower leg muscles with different levels of cold exposure. Eur J Appl Physiol 1997; 75 : 484-490

13) Sargeant AJ : Effect of muscle temperature on leg extension force and short-term power output in humans. Eur J Appl Physiol 1987 ; 56 : 693-698 